\title{
Post-traumatic Stress Disorder and Cardiovascular Disease
}

\author{
Steven S. Coughlin*
}

Environmental Epidemiology Service, Environmental Health Strategic Healthcare Group, Office of Public Health and Environmental Hazards, Department of Veterans Affairs, Washington, DC, USA

\begin{abstract}
This review provides an up-to-date summary of the evidence from clinical and epidemiologic studies indicating that persons with post-traumatic stress disorder (PTSD) may have an increased risk of coronary heart disease and possibly thromboembolic stroke. Persons with PTSD, a common anxiety disorder in both veteran and nonveteran populations, have been reported to have an increased risk of hypertension, hyperlipidemia, obesity, and cardiovascular disease. Increased activity of the sympathoadrenal axis may contribute to cardiovascular disease through the effects of catecholamines on the heart, vasculature, and platelet function. Reported links between PTSD and hypertension and other cardiovascular risk factors may partly account for reported associations between PTSD and heart disease. The associations observed between PTSD and cardiovascular diseases have implications for cardiology practice and research.
\end{abstract}

Keywords: Anxiety disorders, coronary heart disease, hypertension, hyperlipidemia, post-traumatic stress disorder, stroke, veterans.

\section{INTRODUCTION}

An increasing body of evidence indicates that posttraumatic stress disorder, a common anxiety disorder in both veteran and nonveteran populations, is associated with major forms of cardiovascular disease including those attributed to atherosclerosis such as coronary heart disease and thromboembolic stroke. Persons with PTSD have also been reported to be more likely to have hypertension, hyperlipidemia, obesity, and cardiovascular disease [1]. These findings are important to the field of cardiology since coronary heart disease may develop over time as a result of hemodynamic factors (for example, elevated blood pressure with turbulence and sheer stress within coronary arteries), hyperlipidemia, and events such as the rupture of atherosclerotic plaques and thrombus formation [2]. This review summarizes cardiovascular alterations linked to PTSD including results from epidemiologic and clinical studies and possible biological mechanisms.

\section{BACKGROUND}

Individuals may develop PTSD after being exposed to a traumatic event such as combat experiences, a motor vehicle crash, or sexual assault [3]. Symptoms of PTSD may include nightmares, intrusive thoughts, or other re-experiencing phenomena, the avoidance of situations that remind the person of the traumatic event, a feeling of numbness or being socially detached from family and friends, and hyper-arousal (for example, feeling angry, irritable and "on edge," or having difficulty concentrating). Hyper-arousal or hypervigilance includes a rapid and pronounced reaction to

*Address correspondence to this author at the Environmental Epidemiology Service (135), Environmental Health Strategic Healthcare Group, Office of Public Health and Environmental Hazards, 810 Vermont Avenue, NW, Washington, DC 20420, USA; Tel: (202) 266-4656;

E-mail steven.coughlin@va.gov stressors which may lead to a preoccupation with signs of threat and emotional distress. Persons with PTSD may have other challenges such as difficulties with employment, relationships, or other health conditions (for example, depression, alcohol abuse or drug dependency).

Effective psychological and medical treatments for PTSD include group or individual psychotherapy (for example, cognitive-behavioral therapy) and pharmacotherapy such as the use of selective serotonin reuptake inhibitors [4]. Cognitive-behavioral therapy helps patients to address their traumatic memories and distorted cognitions (for example, by providing education about the nature of PTSD and stress responses and helping the individual with the integration of the traumatic events).

\section{CARDIOVASCULAR ALTERATIONS ASSOCIATED WITH PTSD}

Cardiovascular alterations associated with autonomic arousal and cardiovascular health outcomes have long been reported to be associated with PTSD or wartime traumatic exposure [1,5]. Persons suffering from PTSD and chronic PTSD have been shown to have increases in basal heart rate and blood pressure and increased heart rate and blood pressure in response to stimuli such as loud sounds and visual slides that remind them of the trauma [6-9]. In clinical studies involving small samples of veterans, plasma norepinephrine and 24-hour urine norepinephrine levels have been reported to be elevated among veterans with PTSD as compared to those without PTSD [10]. The increases in plasma norepinephrine are more pronounced when PTSD patients are exposed to trauma-related stimuli such as loud tones [11]. Stress and anxiety have been associated with increased plasma and urinary norepinephrine, epinephrine, and their metabolites, which are peripheral measures of the noradrenergic system, in healthy adults $[8,12]$. 
The effects of traumatic exposures or chronic stress on the hypothalamic pituitary adrenal axis (HPA) and the autonomic nervous system have been examined in clinical studies and in animal models. The results of these studies indicate that PTSD can result in important neurobiologic and psychophysiologic changes [1]. Physiological dysregulation of the HPA axis and altered autonomic function may contribute to increases in cardiovascular risk factors reported in persons with PTSD. Increased activity of the sympathoadrenal axis might contribute to cardiovascular disease through the effects of catecholamines on the heart, vasculature, and platelet function [8]. Platelet function is altered by elevated levels of circulating catecholamines. Catecholamines act on alpha-2a receptors on platelet membranes leading to increased platelet aggregation and other changes in platelet function [8, 13]. Catecholamine-induced alterations of platelet activity have been hypothesized to be a link between chronic stress, increased sympathoadrenal activation, and cardiovascular disease $[13,14]$.

Studies have shown that patients with PTSD have higher heart rates at rest and reduced heart rate variability which is consistent with increased sympathetic activity $[8,15]$. The finding that baseline heart rate is higher among veterans suffering from PTSD than among those without PTSD is consistent with chronic hyperstimulation of the autonomic nervous system. Alternatively, the finding could be an artifact due to the research participants being anxious about the impending psychophysiological assessment [16]. The individuals who participated in the studies may have experienced anxiety because they were anticipating exposure to stimuli that would remind them of traumatic events [8]. McFall et al. [17] examined basal heart rates, systolic and diastolic blood pressures among veterans with and without PTSD over an extended period and did not find any significant differences between the two groups. However, in a separate study by Gerardi et al. [6] which included 32 Vietnam veterans with combat-related PTSD and 26 Vietnam era veterans with no combat exposures, those with PTSD had significantly higher heart rate, systolic and diastolic blood pressure. Buckley and Kaloupek [18] completed a meta-analysis of reported studies of basal heart rate and blood pressure among persons with and without PTSD. A total of 34 studies were included with a total sample size across studies of 2,670 subjects. Their results suggested that, on average, persons with PTSD have an elevated basal heart rate as compared with persons without PTSD or those who were not exposed to trauma [18]. The average difference in resting heart rate between persons with or without PTSD was 5 beats per minute. Their metaanalysis also suggested that PTSD is associated with blood pressure elevations [18].

\section{STUDIES OF PTSD AND HYPERTENSION}

PTSD was associated with an increased risk of hypertension in the National Comorbidity Survey and in an epidemiologic study of Vietnam veterans from Australia [19, 20]. Since elevated diastolic and systolic blood pressure are established risk factors for cardiovascular disease, the apparent link between PTSD and hypertension may partly account for reported associations between PTSD and heart disease [1]. Cohen et al. [15] examined associations between PTSD and hypertension and other cardiovascular risk factors using national data from veterans of Operation Enduring Freedom and Operation Iraqi Freedom (OEF/OIF) who sought care at VA health care facilities. The majority of the PTSD patients in their cross-sectional study had comorbid mental health diagnoses including depression (53\%), other anxiety disorder $(29 \%)$, substance abuse disorder $(10 \%)$ and other psychiatric diagnoses $(33 \%)$. Veterans with mental health diagnoses had a significantly higher frequency of hypertension and other cardiovascular disease risk factors [15]. For example, among 65,603 male OEF/OIF veterans who had PTSD with or without other mental health diagnoses, the adjusted odds ratio for the association between PTSD and hypertension was 2.88 (95\% confidence interval 2.79-2.97) after controlling for age, race (white, black, Hispanic, or other), component type, rank, branch of service, and multiple deployments [15]. Among 6,964 female OEF/OIF veterans who had PTSD with or without other mental health diagnoses, the adjusted odds ratio for the association between PTSD and hypertension was 2.88 (95\% confidence interval 2.79-2.97) after controlling for age, race/ethnicity (white, black, Hispanic, or other), component type, rank, branch of service, and multiple deployments [15].

\section{PTSD AND HYPERLIPIDEMIA}

There is increasing evidence from clinical studies that PTSD may have effects on lipid metabolism [21, 22]. Karlovic et al. [23] examined total cholesterol, LDL and HDL cholesterol, and triglycerides in Croatian war veterans with PTSD and patients with major depression. Those with PTSD had higher levels of cholesterol and LDL cholesterol, and triglycerides, on average, and lower HDL cholesterol levels as compared with the patients with major depression. In the study by Cohen et al. [15] of associations between PTSD and cardiovascular risk factors among OEF/OIF veterans who sought care at VA health care facilities, veterans with mental health diagnoses had a significantly higher frequency of dyslipidemia [15]. For example, among 65,603 male OEF/OIF veterans who had PTSD with or without other mental health diagnoses, the adjusted odds ratio for the association between PTSD and dyslipidemia was 2.70 (95\% confidence interval 2.63-2.78) after controlling for age, race/ethnicity (white, black, Hispanic, or other), component type, rank, branch of service, and multiple deployments [15]. Among 6,964 female OEF/OIF veterans who had PTSD with or without other mental health diagnoses, the adjusted odds ratio for the association between PTSD and dyslipidemia was 2.68 (95\% confidence interval 2.44-2.95) after controlling for age, race/ethnicity (white, black, Hispanic, or other), component type, rank, branch of service, and multiple deployments [15]. Elevated levels of total cholesterol and triglycerides have also been observed among Brazilian police officers with PTSD [24].

\section{STUDIES OF PTSD AND CORONARY HEART DIS- EASE}

Positive associations between PTSD and cardiovascular disease (particularly coronary heart disease) have been observed in a growing number of studies of veterans and civilians who were exposed to combat or other traumatic experiences, as summarized in Table 1. Some of these studies were retrospective, relied upon self-reported information about cardiovascular disease, or had other design limitations $[2,25-31,35,36]$. Nevertheless, an increasing number of 
Table 1. Studies of PTSD and Cardiovascular Disease among Veterans and Civilian Populations Exposed to Traumatic Experiences

\begin{tabular}{|c|c|c|c|c|c|}
\hline Study & Sample & Study Design & Results & Limitations & Other Information \\
\hline $\begin{array}{l}\text { Falger et al. } \\
\text { (1992) }\end{array}$ & $\begin{array}{l}\text { Male WW II Dutch } \\
\text { Resistance veterans } \\
(\mathrm{n}=147) \text {, aged } 60-65 \\
\text { years, and age and sex- } \\
\text { matched controls with } \\
\text { recent hospitalization } \\
\text { for MI }(\mathrm{n}=65) \text { or sur- } \\
\text { gery }(\mathrm{n}=79) \text {. }\end{array}$ & $\begin{array}{l}\text { Clinical interviews of } \\
\text { surviving veterans } \\
\text { conducted more than } 4 \\
\text { decades after the war } \\
\text { had ended. PTSD was } \\
\text { assessed using struc- } \\
\text { tured interviews based } \\
\text { on DSM-III. }\end{array}$ & $\begin{array}{l}\text { The Resistance veterans, especially } \\
\text { those with PTSD, scored higher than } \\
\text { the matched controls on angina pec- } \\
\text { toris, type A behavior, life stressors, } \\
\text { and vital exhaustion. About } 10 \% \text { of } \\
\text { the veterans reported having had an } \\
\text { MI in the past } 15 \text { years. About } 56 \% \\
\text { percent of the veterans were currently } \\
\text { suffering from PTSD. }\end{array}$ & $\begin{array}{l}\text { The use of controls } \\
\text { with recent MI may } \\
\text { have partly obscured } \\
\text { associations with } \\
\text { cardiovascular risk } \\
\text { factors. History of } \\
\text { MI was based on } \\
\text { self-reported } \\
\text { information. }\end{array}$ & $\begin{array}{l}\text { Half of these Resistance } \\
\text { veterans had been ar- } \\
\text { rested and incarcerated } \\
\text { in Nazi prisons and } \\
\text { forced labor and death } \\
\text { camps. All were exposed } \\
\text { to extraordinary war- } \\
\text { time trauma. }\end{array}$ \\
\hline $\begin{array}{l}\text { Boscarino } \\
(1997)\end{array}$ & $\begin{array}{l}\text { National sample of male } \\
\text { Vietnam veterans } \\
(\mathrm{n}=1,399) \text { who served in } \\
\text { the U.S. Army. }\end{array}$ & $\begin{array}{l}\text { In-person interviews } \\
\text { conducted about } 20 \\
\text { years post combat expo- } \\
\text { sure. Circulatory dis- } \\
\text { eases were assessed } \\
\text { retrospectively. }\end{array}$ & $\begin{array}{l}\text { After controlling for age, race, region } \\
\text { of birth, enlistment status, volunteer } \\
\text { status, Army marital status, Army } \\
\text { medical profile, smoking history, } \\
\text { substance abuse, education, income, } \\
\text { and other factors, lifetime PTSD } \\
\text { status was associated with reported } \\
\text { circulatory diseases (OR = } 1.62, \mathrm{p}= \\
.007 \text { ) and other illnesses after mili- } \\
\text { tary service. About } 63 \%(\mathrm{n}=332) \text { had } \\
\text { a lifetime history of PTSD. }\end{array}$ & $\begin{array}{l}\text { Self-reported } \\
\text { information about } \\
\text { disease history was } \\
\text { used in the analysis. } \\
\text { The response rate } \\
\text { was } 65 \% \text {. }\end{array}$ & \\
\hline $\begin{array}{l}\text { Boscarino and } \\
\text { Chang (1999) }\end{array}$ & $\begin{array}{l}\text { National sample of male } \\
\text { U.S. Army veterans } \\
\text { who served in theatre } \\
\text { during the Vietnam war } \\
(\mathrm{n}=2,490) \text { or during the } \\
\text { same era }(\mathrm{n}=1,972) .\end{array}$ & $\begin{array}{l}\text { Medical examinations } \\
\text { (conducted about } 17 \\
\text { years after combat } \\
\text { exposures for Vietnam } \\
\text { theatre veterans). Psy- } \\
\text { chiatric evaluations } \\
\text { included the Diagnostic } \\
\text { Interview Schedule } \\
\text { based on DSM-III. }\end{array}$ & $\begin{array}{l}\text { After controlling for age, place of } \\
\text { service, illicit drug use, medication } \\
\text { use, race, body mass index, alcohol } \\
\text { use, cigarette smoking, and educa- } \\
\text { tion, PTSD was associated with ECG } \\
\text { findings including atrioventricular } \\
\text { conduction defects (OR }=2.81,95 \% \\
\text { CI } 1.03-7.66, p<0.05) \text { and infarc- } \\
\text { tions }(\mathrm{OR}=4.44,95 \% \text { CI } 1.20-16.43 \text {, } \\
\text { p }<0.05) \text {. }\end{array}$ & $\begin{array}{l}\text { The overall partici- } \\
\text { pation rate was } 60 \% \text {. } \\
\text { Soldiers who served } \\
\text { in theatre may have } \\
\text { had greater exposure } \\
\text { to toxic chemicals. }\end{array}$ & $\begin{array}{l}\text { The average age of first } \\
\text { onset of PTSD was } 21 \\
\text { years. }\end{array}$ \\
\hline $\begin{array}{l}\text { Boscarino } \\
(2006)\end{array}$ & $\begin{array}{l}\text { National sample of male } \\
\text { U.S. Army veterans } \\
(\mathrm{n}=15,288) \text { who served } \\
\text { during the Vietnam War } \\
\text { era. }\end{array}$ & $\begin{array}{l}\text { Cohort mortality study } \\
\text { with } 16 \text { years of follow- } \\
\text { up following completion } \\
\text { of a telephone survey } \\
\text { (or about } 30 \text { years after } \\
\text { their military service). }\end{array}$ & $\begin{array}{l}\text { After controlling for race, Army } \\
\text { volunteer status, entry age, and dis- } \\
\text { charge status, Army illicit drug } \\
\text { abuse, age, and other factors, PTSD } \\
\text { among Vietnam theatre veterans was } \\
\text { associated with cardiovascular mor- } \\
\text { tality (hazards ratio }=1.7, \mathrm{p}=0.034 \text { ), } \\
\text { all-cause mortality, cancer, and } \\
\text { external causes of death. }\end{array}$ & $\begin{array}{l}\text { Adjustment was } \\
\text { made for pack-years } \\
\text { of cigarette smoking } \\
\text { only when looking } \\
\text { at cancer mortality. }\end{array}$ & \\
\hline $\begin{array}{l}\text { Boscarino } \\
(2008)\end{array}$ & $\begin{array}{l}\text { National sample of male } \\
\text { Vietnam veterans } \\
(n=4,328) \text { who served in } \\
\text { the U.S. Army. The men } \\
\text { were }<65 \text { years of age } \\
\text { at follow-up. }\end{array}$ & Cohort mortality study & $\begin{array}{l}\text { PTSD was assessed using two meas- } \\
\text { ures include one based on DSM-III. } \\
\text { Having more PTSD symptoms was } \\
\text { positively associated with early-age } \\
\text { heart disease mortality. }\end{array}$ & & \\
\hline $\begin{array}{l}\text { Dobie et al. } \\
\text { (2004) }\end{array}$ & $\begin{array}{l}\text { Female veterans } \\
(\mathrm{n}=1,259) \text { who received } \\
\text { care at the VA Puget } \\
\text { Sound Health Care } \\
\text { System between Octo- } \\
\text { ber } 1996 \text { and January } \\
1998\end{array}$ & $\begin{array}{l}\text { Cross-sectional postal } \\
\text { survey }\end{array}$ & $\begin{array}{l}\text { Of the eligible women who com- } \\
\text { pleted the survey, } 21 \% \text { screened } \\
\text { positive for current PTSD (PTSD } \\
\text { Checklist-Civilian Version score } \geq \\
\text { 50). A statistically nonsignificant } \\
\text { association was observed with myo- } \\
\text { cardial infarction or coronary artery } \\
\text { disease (OR }=1.8,95 \% \text { CI } 0.9-3.6 \text { ). }\end{array}$ & $\begin{array}{l}\text { Study limitations } \\
\text { include the cross- } \\
\text { sectional design and } \\
\text { the reliance on self- } \\
\text { reported information } \\
\text { about medical con- } \\
\text { ditions. }\end{array}$ & \\
\hline
\end{tabular}


Table 1. contd....

\begin{tabular}{|c|c|c|c|c|c|}
\hline $\begin{array}{l}\text { Kang et al. } \\
(2006)\end{array}$ & $\begin{array}{l}\text { Former WW II prison- } \\
\text { ers of war ( } \mathrm{n}=19,442) \\
\text { and non POW controls } \\
(\mathrm{n}=9,728)\end{array}$ & $\begin{array}{l}\text { Review of healthcare } \\
\text { utilization data for } 10 \\
\text { years (1991-2000) from } \\
\text { VA and non-VA } \\
\text { healthcare providers. }\end{array}$ & $\begin{array}{l}\text { After adjustment for age and race, } \\
\text { former POWs with PTSD had statis- } \\
\text { tically significant increased risks of } \\
\text { CVD, including ischemic heart dis- } \\
\text { ease and hypertension, as compared } \\
\text { with both non-POWS and POWs } \\
\text { without PTSD. The magnitude of the } \\
\text { increased risk of ischemic heart } \\
\text { disease was modest. }\end{array}$ & $\begin{array}{l}\text { POWs might be } \\
\text { more likely than the } \\
\text { study controls to be } \\
\text { in VA medical } \\
\text { treatment files. }\end{array}$ & \\
\hline $\begin{array}{l}\text { Schnurr } \\
\text { et al. }(2000)\end{array}$ & $\begin{array}{l}\text { Male combat veterans } \\
\text { of WW II and the Koren } \\
\text { conflict ( } \mathrm{n}=605) \text {. The } \\
\text { average age at study } \\
\text { entry was } 43.9 \text { years. } \\
\text { The majority of the men } \\
(98 \%) \text { were white. }\end{array}$ & $\begin{array}{l}\text { Follow-up study. Medi- } \\
\text { cal examinations were } \\
\text { performed periodically } \\
\text { beginning in } 1960 . \\
\text { PTSD symptoms were } \\
\text { assessed in } 1990 .\end{array}$ & $\begin{array}{l}\text { PTSD was assessed using the Missis- } \\
\text { sippi Scale for Combat-Related } \\
\text { PTSD. PTSD symptoms were posi- } \\
\text { tively associated with the onset of } \\
\text { arterial disorders (hazard ratio }=1.3 \text {, } \\
95 \% \text { CI 1.2-1.5) after controlling for } \\
\text { age, smoking, alcohol consumption, } \\
\text { and body mass index. The hazard } \\
\text { ratios for hypertensive and ischemic } \\
\text { cardiovascular disease were not } \\
\text { significantly different than one. }\end{array}$ & $\begin{array}{l}\text { PTSD was not meas- } \\
\text { ured at the } \\
\text { beginning of the } \\
\text { study but rather in } \\
1990 \text { after many of } \\
\text { the outcomes had } \\
\text { already occurred. }\end{array}$ & \\
\hline $\begin{array}{l}\text { Kubzansky } \\
\text { et al. (2007) }\end{array}$ & $\begin{array}{l}\text { Community dwelling } \\
\text { men }(\mathrm{n}=1,002) \text { from the } \\
\text { greater Boston, } \\
\text { Massachusetts area who } \\
\text { were aged } 21 \text { to } 80 \\
\text { years in } 1961 \text {. Over } \\
90 \% \text { of the men are } \\
\text { veterans and most were } \\
\text { white. Men with } \\
\text { preexisting coronary } \\
\text { heart disease or diabetes }\end{array}$ & $\begin{array}{l}\text { Prospective cohort } \\
\text { study. }\end{array}$ & $\begin{array}{l}\text { PTSD was assessed using the Missis- } \\
\text { sippi Scale for Combat-Related } \\
\text { PTSD. For each standard deviation } \\
\text { increase in PTSD symptom level, the } \\
\text { age-adjusted relative risk for nonfatal } \\
\text { and fatal myocardial infarction com- } \\
\text { bined was } 1.3 \text { ( } 95 \% \text { CI 1.05-1.5). }\end{array}$ & & $\begin{array}{l}\text { The data were from the } \\
\text { VA Normative Aging } \\
\text { Study. }\end{array}$ \\
\hline $\begin{array}{l}\text { Dirkzwager } \\
\text { et al. (2007) }\end{array}$ & $\begin{array}{l}\text { Sample of adult survi- } \\
\text { vors ( } \mathrm{n}=896 \text { ) of a fire } \\
\text { disaster in Enschede, } \\
\text { Netherlands that killed } \\
23 \text { persons and de- } \\
\text { stroyed or damaged } \\
\text { almost } 1,500 \text { houses. }\end{array}$ & $\begin{array}{l}\text { Longitudinal design. } \\
\text { Electronic medical } \\
\text { records from family } \\
\text { practitioners ( } 1 \text { year and } \\
4 \text { years post disaster) } \\
\text { were used. Survey data } \\
\text { were also collected at } 3 \\
\text { weeks and } 18 \text { months } \\
\text { post disaster to assess } \\
\text { PTSD and physical } \\
\text { health. }\end{array}$ & $\begin{array}{l}\text { The Self-Rating Scale for PTSD was } \\
\text { used to assess the condition. After } \\
\text { controlling for demographic factors, } \\
\text { smoking, and predisaster physical } \\
\text { health, PTSD was positively associ- } \\
\text { ated with risk of new vascular prob- } \\
\text { lems (OR }=1.9,95 \% \text { CI 1.04-3.6). }\end{array}$ & & \\
\hline
\end{tabular}


Table 1. contd....

\begin{tabular}{|c|c|c|c|c|c|}
\hline Study & Sample & Study Design & Results & Limitations & Other Information \\
\hline $\begin{array}{l}\text { Spitzer } \\
\text { et al. (2009) }\end{array}$ & $\begin{array}{l}\text { Community dwelling } \\
\text { adults in Germany } \\
(\mathrm{n}=3,171)\end{array}$ & Cross-sectional survey & $\begin{array}{l}\text { PTSD was assessed using the Struc- } \\
\text { tured Clinical Interview for DSM-IV. } \\
\text { After controlling for demographic } \\
\text { factors, smoking, body mass index, } \\
\text { blood pressure, depression, and } \\
\text { alcohol use disorders, PTSD was } \\
\text { positively associated with angina } \\
(\mathrm{OR}=2.4,95 \% \text { CI } 1.3-4.5) \text {, heart } \\
\text { failure (OR }=3.4,95 \% \text { CI } 1.9-6.0) \text {, } \\
\text { and peripheral arterial disease. }\end{array}$ & $\begin{array}{l}\text { Study limitations } \\
\text { include the } \\
\text { cross-sectional } \\
\text { design and the } \\
\text { reliance on self- } \\
\text { reported information } \\
\text { about medical } \\
\text { conditions. }\end{array}$ & \\
\hline $\begin{array}{l}\text { Johnson } \\
\text { et al. }(2010)\end{array}$ & $\begin{array}{l}\text { Male residents of four } \\
\text { U.S. communities } \\
(n=5,347)\end{array}$ & $\begin{array}{l}\text { Population-based study of } \\
\text { the prevalence of } \\
\text { subclinical atherosclerosis } \\
\text { (carotid intima thickness } \\
\text { and carotid plaque) } \\
\text { measured noninvasively } \\
\text { at two study visits } \\
\text { (1987-1989 and } \\
\text { 1990-1992). }\end{array}$ & $\begin{array}{l}\text { Compared to non-combat veterans, } \\
\text { non-veterans and combat veterans } \\
\text { had higher age-adjusted mean carotid } \\
\text { intima thickness. Differences } \\
\text { remained for combat veterans after } \\
\text { adjustment for race, father's educa- } \\
\text { tion, and age at service entry but not } \\
\text { years of service. No differences in } \\
\text { carotid plaque were noted. }\end{array}$ & $\begin{array}{l}\text { PTSD was not as- } \\
\text { sessed in this study. }\end{array}$ & $\begin{array}{l}\text { The data were from the } \\
\text { Atherosclerosis Risk in } \\
\text { Communities (ARIC) } \\
\text { Study. }\end{array}$ \\
\hline
\end{tabular}

studies have prospectively examined PTSD as a predictor of physician-diagnosed cardiovascular disease [32-34]. Taken overall, these results from observational research provide considerable evidence that persons with PTSD have an increased risk of coronary heart disease morbidity and mortality.

\section{PTSD AND CEREBRAL VASCULAR DISEASE}

There is some evidence from epidemiologic studies of an association between PTSD and cerebrovascular disease. Brass and Page [37] found that former World War II prisoners of war (POWs) had a statistically nonsignificant increased risk of stroke. Among the 475 former POWs, $12.7 \%$ (20 of 158) of those with PTSD had strokes, compared with $7.6 \%$ (24 of 317) without PTSD (relative risk $=1.7,95 \%$ confidence interval 0.95 to 2.9 ). In a cross-sectional survey of female veteran's who received care at the VA Puget Sound Health Care System, Dobie et al. [29] found an association between PTSD and self-reported history of stroke. About 5\% (13 of 256) of the female veterans with PTSD reported a history of stroke as compared with 3\% (28 of 905) of those without PTSD (age-adjusted odds ratio $=2.9,95 \%$ confidence interval 1.4-6.0) [29]. A study of trauma and PTSD among 3,171 male and female adults living in the general population of a German community found that persons with a history of trauma had a higher odds of stroke (odds ratio $=1.2,95 \%$ confidence interval 1.0-1.5), angina pectoris, and heart failure after adjustment for demographic factors, blood pressure, smoking, body mass index, depression, and alcohol-related disorders [35].

\section{DISCUSSION}

This review of the published literature highlights evidence from epidemiologic and clinical studies that persons with PTSD are at increased risk of cardiovascular disease including coronary heart disease and possibly stroke. These findings have several implications for cardiologists and cardiovascular researchers. Anxiety disorders such as PTSD are common in the general population [4]. In addition, combat veterans have an increased risk of PTSD [3, 4]. Clinicians who see patients in primary care practice or in cardiology clinics should be aware that longstanding PTSD may have deleterious effects on the cardiovascular system including increased risk of coronary heart disease and hypertension. Cardiologists routinely talk with patients about alcohol drinking and cigarette smoking, both of which may be more frequent among persons suffering from PTSD. Effective evidence-based treatments are available for persons with PTSD including those who suffer from dual diagnoses such as PTSD and alcohol dependence [4].

The biological mechanisms that account for the observed associations between PTSD and cardiovascular disease may relate to the effects of traumatic exposures and chronic stress on the HPA axis and the autonomic nervous system [8]. Dysregulation of the HPA axis and chronic over-stimulation of the autonomic nervous system may contribute to the increases in blood pressure and lipid levels that have been observed in PTSD patients. Catecholamine-induced alterations of platelet activity may also contribute to the apparent link between PTSD and cardiovascular disease. Changes in immune function seen in some PTSD patients may also have a role including circulating levels of interleukin-6 (IL-6), IL-1, tumor necrosis factor, and C-reactive protein [38]. Inflammatory mediators such as IL-6, tumor necrosis factor, and Creactive protein have been reported to stimulate atherosclerosis [38]. Interactions among the immune and neuroendocrine systems may partly account for associations between PTSD and chronic disease outcomes. 
Previous authors have proposed general models of possible mechanisms underlying the relationship between PTSD and physical health including cardiovascular disease [31]. The models take into account biological function (e.g., HPA axis, heightened noradrenergic function, immune function), psychological comorbidities such as depression, health risk behaviors, symptom reports and functional status, and disease morbidity and mortality. A similar model of PTSD outcomes proposed by Boscarino accounts for different pathways leading to changes in health status; the influences of heredity, shared environment, history of trauma, behavior and perceptions, biological changes, and stressful life event exposures are taken into account in the model [5].

In conclusion, persons with PTSD have been reported to have an increased risk of hypertension, hyperlipidemia, obesity, and cardiovascular disease. Such persons have been observed to have an increased risk of coronary heart disease and possibly thromboembolic stroke. The reported link between PTSD and hypertension and other cardiovascular risk factors may partly account for the observed associations between PTSD and heart disease.

\section{ABBREVIATIONS}

$\begin{array}{lll}\text { DSM } & =\begin{array}{l}\text { Diagnostic and Statistical Manual of Mental } \\ \text { Disorders }\end{array} \\ \text { LDL } & = & \text { Low Density Lipoprotein } \\ \text { HPA } & = & \text { Hypothalamic Pituitary Adrenal Axis } \\ \text { IL-6 } & = & \text { Interleukin-6 } \\ \text { LDL } & = & \text { Low Density Lipoprotein } \\ \text { OR } & = & \text { Odds Ratio } \\ \text { OEF/OIF } & =\text { Operation Enduring Freedom/Operation Iraqi } \\ \text { POWs } & =\text { Prisoners of War } \\ \text { PTSD } & =\text { Post-traumatic Stress Disorder } \\ \text { VA } & =\text { Department of Veterans Affairs }\end{array}$

\section{REFERENCES}

[1] McFarlane AC. The long-term costs of traumatic stress: intertwined physical and psychological consequences. World Psychiatry 2010; 9: 3-10.

[2] Boscarino JA, Chang J. Electrocardiogram abnormalities among men with stress-related psychiatric disorders: implications for coronary heart disease and clinical research. Ann Behavioral Med 1999; $21: 227-34$.

[3] Friedman MJ, Keane TM, Resick PA, ed. Handbook of PTSD. Science and Pratice. New York: The Guilford Press 2007.

[4] Spoont MR, Murdoch M, Hodges J, Nugent S. Treatment receipt by Veterans after a PTSD diagnosis in PTSD, mental health, or general medical clinics. Psychiatric Services 2010; 61: 58-63.

[5] Boscarino JA. Posttraumatic stress disorder and physical illness. Results from clinical and epidemiologic studies. Ann NY Acad Sci 2004;1032: 141-53.

[6] Gerardi RJ, Keane TM, Cahoon BJ, Klauminzer GW. An in vivo assessment of physiological arousal in posttraumatic stress disorder. J Abn Psychol 1994; 103: 825-7.

[7] Keane TM, Kolb LC, Kaloupek DG, et al. Utility of psychophysiological measurement in the diagnosis of posttraumatic stress disorder: results from a Department of Veterans Affairs cooperative study. J Consult Clin Psychol 1998; 66: 914-23.
[8] Bedi US, Arora R. Cardiovascular manifestations of posttraumatic stress disorder. J National Med Assoc 2007; 99: 642-9.

[9] Kleim B, Wilhelm FH, Glucksman E, Ehlers A. Sex differences in heart rate responses to script-driven imagery soon after trauma and risk of posttraumatic stress disorder. Psychosomatic Med 2010; 72: 917-24.

[10] Mason JW, Giller EL, Kosten TR, Harkness L. Elevation of urinary norepinephrine/cortisol ratio in posttraumatic stress disorder. J Nerv Mental Dis 1988; 176: 498-502.

[11] Shalev AY, Orr SP, Peri T, et al. Physiologic responses to loud tones in Israeli patients with posttraumatic stress disorder. Arch Gen Psychiatry 1992; 49: 870-4.

[12] Lader M. The peripheral and central role of the catecholamines in the mechanisms of anxiety. Int Pharmacopsychiatry 1974; 9: 12537.

[13] Anfossi G, Trovati M. Role of catecholamines in platelet function: patho-physiological and clinical significance. Eur J Clin Invest 1996; 26: 353-70.

[14] Vidovic A, Grubisic-llic M, Kozaric-Kovacic D, et al. Exaggerated platelet reactivity to physiological agonists in war veterans with posttraumatic stress disorder. Psychoneuroendocrinology 2010

[15] Cohen BE, Marmar C, Ren L, et al. Association of cardiovascular risk factors with mental health diagnoses in Iraq and Afghanistan war veterans using VA health care. JAMA 2009; 302: 489-92.

[16] Blanchard EB. Elevated basal levels of cardiovascular responses in Vietnam veterans with PTSD: a health problem in the making? J Anxiety Disord 1990; 4: 233-7.

[17] McFall ME, Veith RC, Murburg MM. Basal sympathoadrenal function in posttraumatic stress disorder. Biol Psychiatry 1992; 31: 1050-6.

[18] Buckley TC, Kaloupek DG. A meta-analytic examination of basal cardiovascular activity in posttraumatic stress disorder. Psychosomatic Med 2001; 63: 585-94.

[19] Kibler JL, Joshi K, Ma M. Hypertension in relation to posttraumatic stress disorder and depression in the US National Comorbidity Survey. Behav Med 2009; 34: 125-32.

[20] O'Toole BI, Catts SV. Trauma, PTSD, and physical health: an epidemiological study of Australian Vietnam veterans. J Psychosom Res 2008; 64: 33-40.

[21] Solter V, Thaller V, Karlovic D, et al. Elevated serum lipids in veterans with combat-related chronic posttraumatic stress disorder. Croat Med J 2002; 43: 685-9.

[22] Kagan BL, Leskin G, Haas B, et al. Elevated lipid levels in Vietnam veterans with chronic posttraumatic stress disorder. Biol Psychiatry 1999; 45: 374-7.

[23] Karlovic D, Buljan D, Martinac M, et al. Serum lipid concentrations in Croatian veterans with post-traumatic stress disorder, posttraumatic stress disorder comorbid with major depressive disorder, or major depressive disorder. J Korean Med Sci 2004; 19: 431-6.

[24] Maia DB, Marmar CR, Mendlowicz MV, et al. Abnormal serum lipid profile in Brazilian police officers with post-traumatic stress disorder. J Affect Disord 2008; 107: 259-63.

[25] Falger PRJ, Op den Velde W, Hovens JE. Current posttraumatic stress disorder and cardiovascular risk factors in Dutch resistance veterans from World War II. Psychother Psychosom 1992; 57: 164-71.

[26] Boscarino JA. Diseases among men 20 years after exposure to severe stress: implications for clinical research and medical care. Psychosomatic Med 1997; 59: 605-14.

[27] Boscarino JA. Posttraumatic stress disorder and mortality among U.S. Army veterans 30 years after military service. Ann Epidemiol 2006; 16: 248-56.

[28] Boscarino JA. A prospective study of PTSD and early-age heart disease mortality among Vietnam veterans: implications for surveillance and prevention. Psychosomatic Med 2008; 70: 668-76.

[29] Dobie DJ, Kivlahan DR, Maynard C, et al. Postraumatic stress disorder in female veterans. Association with self-reported health problems and functional impairment. Arch Intern Med 2004; 164 : 394-400.

[30] Kang HK, Bullman TA, Taylor JW. Risk of selected cardiovascular diseases and posttraumatic stress disorder among former World War II prisoners of war. Ann Epidemiol 2006; 16: 381-6.

[31] Schnurr PP, Green BL. Understanding relationships among trauma, post-traumatic stress disorder, and health outcomes. Advances Spring 2004; 20: 18-29. 
[32] Kubzansky LD, Koenen KC, Spiro A III, et al. Prospective study of posttraumatic stress disorder symptoms and coronary heart disease in the Normative Aging Study. Arch Gen Psychiatry 2007; 64: 10916.

[33] Kubzansky LD, Koenen KC, Jones C, Eaton WW. A prospective study of posttraumatic stress disorder symptoms and coronary heart disease in women. Health Psychol 2009; 28: 125-30.

[34] Dirkzwager AJE, van der Velden PG, Grievink L, Yzermans CJ. Disaster-related posttraumatic stress disorder and physical health. Psychosomatic Med 2007; 69: 435-40.
[35] Spitzer C, Barnow S, Volzke H, et al. Trauma, posttraumatic stress disorder, and physical illness: findings from the general population. Psychosom Med 2009; 71: 1012-7.

[36] Johnson AM, Rose KM, Elder GH Jr, et al. Military combat and burden of subclinical atherosclerosis in middle aged men: the ARIC study. Prev Med 2010; 50: 277-81.

[37] Brass LM, Page WF. Stroke in former prisoners of war. J Stroke Cerebrovasc Dis 1996; 6: 72-8.

[38] Rohleder N, Karl A. Role of endocrine and inflammatory alterations in comorbid somatic diseases of post-traumatic stress disorder. Minerva Endocrinologica 2006; 31:273-88.

(C) Steven S. Coughlin; Licensee Bentham Open.

This is an open access article licensed under the terms of the Creative Commons Attribution Non-Commercial License (http://creativecommons.org/licenses/ by-nc/3.0/) which permits unrestricted, non-commercial use, distribution and reproduction in any medium, provided the work is properly cited. 